Creative Commons User License: CC BY-NC-ND

Abstracted by: EBSCOhost, Electronic Journals Service (EJS), Google Scholar, Journal Seek, Scientific Commons,

Food and Agricultural Organization (FAO), CABI and Scopus

http://eoi.citefactor.org/10.11226/v25i1
Journal of Agricultural Extension

Vol. 25 (1) January, 2021

ISSN(e): 24086851; ISSN(Print); 1119944X

http://journal.aesonnigeria.org

http://www.ajol.info/index.php/jae

Email: editorinchief@aesonnigeria.org

\title{
Extension Agents' Use of Mobile Phone Applications for Agricultural Extension Service Delivery in Ebonyi State Agricultural Development Programme, Nigeria
}

https://dx.doi.org/10.4314/jae.v25i1.6

\author{
Ezeh, Ann Nnenna \\ Department of Agricultural Economics, Management and Extension, Ebonyi State \\ University, P.M.B 053, Abakaliki, Ebonyi State, Nigeria \\ Email: annezeh2007@yahoo.com;+2348035410610
}

\section{Eze, Anayochukwu Victor}

Department of Agricultural Economics, Kenyatta University, Kenya

Email: ezeanayochukwu09@gmail.com; +2348036718919

\section{Eze, Esther Onyinyechi}

Department of Agricultural Economics, Management \& Extension, Ebonyi State

University, P.M.B 053, Abakaliki, Ebonyi State, Nigeria

Email: igweesther598@yahoo.com; +2348082814748

\section{Abstract}

This study assessed extension agents' use of mobile applications (apps) for extension service delivery in Ebonyi State Agricultural Development Programme (EBADP). The study involved 100 field extension agents. Percentage and mean score derived from 4-point Likert-type scale was employed in the analysis of data. The results of the analysis showed that the most utilized mobile apps for extension service delivery were WhatsApp (76\%) and facebook (53\%). Lowland rice production (65\%), cassava/maize/vegetable production (58\%), and upland rice production (47\%) were the most recommended packages of crop production component that were extended using mobile apps in EBADP. However, the use of mobile apps for extension service delivery were limited as a result of unavailability of network coverage in rural area (84\%), lack of institutional policy for application of mobile apps in extension service (75\%), low ownership of smartphones among farmers (73\%), poor farmers' knowledge on the use of mobile apps (67\%), and poor internet connectivity (66\%). Government should initiate e-extension policy, making mobile apps extension services mandatory for public extension organizations; extension organizations should develop specific mobile apps that will support extension service delivery; and organizing training programmes for extension agents on the use of mobile apps for extension service delivery.

Keywords: Mobile apps, smartphones, extension service, WhatsApp, Facebook

\section{Introduction}


Creative Commons User License: CC BY-NC-ND

Abstracted by: EBSCOhost, Electronic Journals Service (EJS), Google Scholar, Journal Seek, Scientific Commons,

Food and Agricultural Organization (FAO), CABI and Scopus

http://eoi.citefactor.org/10.11226/v25i1
Journal of Agricultural Extension

Vol. 25 (1) January, 2021

ISSN(e): 24086851; ISSN(Print); 1119944X

http://journal.aesonnigeria.org

http://www.ajol.info/index.php/jae

Email: editorinchief@aesonnigeria.org

Agriculture plays a significant role in Nigerian economy. It contributes over 21.9 percent to national GDP in 2019 (National Bureau of Statistics (NBS), 2019), and employs about 70 percent of the nation's population (Urama and Nfor, 2018). It is also the largest livelihood activity in the rural area where close to 50 percent of the population dwells. The role of agricultural extension in agricultural development cannot be overemphasized. Agricultural extension has been the vanguard in the delivery of adequate information to farmers for increased productivity. Globally, agricultural extension service delivery is concerned with extending research outcomes and improved agricultural practices to farmers (Danso-Abbeam, Ehiakpor and Aidoo, 2018). The efficiency with which these information and practices are conveyed to farmers to a large extent determines the level of agricultural productivity.

In Nigeria, the organ charged with public extension service delivery is the Agricultural Development Programme (ADP). The ADP was launched in 1975 as a public extension organization with the Training and Visit (T\&V) extension strategy as its major component (Sennuga, 2019). The popularity of the T\&V system was perhaps due to its ability to promote and encourage professionalism with well-defined structural and institutional components, coupled with the inbuilt monitoring and evaluation system, and flexibility in terms of accommodating other agricultural and rural development programmes (Sennuga and Fadiji, 2020). Over the years, ADP has operated with a number of challenges; notable among these is gross understaffing resulting to high extension agent-farmer ratio. Alluding to this assertion, Sennuga (2019) put the ratio of public extension agents to farmers in Nigeria at 1:3000, which is contrary to the World Bank recommendation of 1:500 (Sennuga and Fadiji, 2020). This large disproportionate ratio makes it imperative for ADP to explore a more effective approach of reaching their greater clients (farmers) at a shortest possible time. One of such approach is the use of mobile phone applications. Mobile phone applications with its high reachability can be used to supplement the $T \& V$ extension approach because it can be used to reach large audience of farmers without necessarily embarking on the costly visits to their farms. Sennuga (2019) noted that the inefficiency and ineffectiveness of $\mathrm{T} \& \mathrm{~V}$ approach as well as the traditional extension systems have given impetus to the discourse for the use of ICTs such as mobile phone applications as a complementary tool for maintaining extension agent-farmer contact.

Mobile phone has become one of the fastest growing ICTs that has found usefulness in extension service delivery for improving agricultural productivity and accelerate development programmes in rural areas (Asa and Uwem, 2017). Ogunniyi and Ojebuyi (2016) acknowledged that the use of mobile phone in agricultural extension can contribute to poverty reduction and socioeconomic development. Sennuga and Fadiji (2020) suggested that the use of mobile phones in extension service can help integrate the marginalized poor farmers into the mainstream through the promotion of communication that is not restricted by time, distance, volume and medium, thereby overcoming 
Creative Commons User License: CC BY-NC-ND

Abstracted by: EBSCOhost, Electronic Journals Service (EJS), Google Scholar, Journal Seek, Scientific Commons,

Food and Agricultural Organization (FAO), CABI and Scopus

http://eoi.citefactor.org/10.11226/v25i1
Journal of Agricultural Extension

Vol. 25 (1) January, 2021

ISSN(e): 24086851; ISSN(Print); 1119944X

http://journal.aesonnigeria.org

http://www.ajol.info/index.php/jae

Email: editorinchief@aesonnigeria.org

barriers occasioned by territorial borders and physical distance. Costopoulou, Ntaliani and Karetsos (2016) are of the view that mobile phone can be applied in agricultural extension to achieve weather prediction, agricultural product market prices, information for agricultural machinery and equipment, farm inputs, water conservation and irrigation management, yield prediction and monitoring, dairy farming, management of agricultural products and crop sensors, and registration of soil types. Mobile phone can aid the actualization of these services because it provides platform that enable various installed mobile applications to be used for several purposes including extension service.

Mobile applications (mobile apps) are software programmes similar to those in desktop and laptop computers, designed to run on mobile devices like smartphones and tablets (Costopoulou et al., 2016). They perform essential and specific functions, ranging from productivity, entertainment and access to information. They are designed to be interactive and provide users with mobile contents such as text, audio, recordings, images, graphics and videos. A number of mobile phone apps have been developed for agriculture in Nigeria. Notable mobile phone apps used in agriculture are Agrikore, FarmCrowdy, Verdant, AgroData, Hello Tractor, and Probityfarms apps (Sennuga and Fadiji, 2020). Agrikore app brings farmers, agro-dealers, commodity traders and insurers together under one platform. FarmCrowdy aids the linking of potential farm investors to farmers. Verdant app offers market information and general agricultural guidance, and AgroData app links farmers to agricultural information from research institutions. Hello Tractor app enables farmers to lease tractors and other farming implements. Probityfarms is used for farm management as well as to connect farmers to market, and Compare-the-market is designed to compare daily market prices of food crops and livestock in Nigeria. Equally, social media apps like WhatsApp, Facebook, Telegram, and Instagram have been used by agricultural actors to create group chat for information sharing and marketing of agro-produce. These mobile phone apps offer extension organizations opportunity of using these platforms to carry out extension programmes.

The use of mobile phone applications enables extension agents to contact larger farmers with appropriate and up-to-date information in a timely manner. Oladele (2015) contended that ICT, particularly mobile phone applications enable extension agents to reach vast number of small-scale farmers simultaneously using their local language with knowledge and information which strengthens and enables farmers to solve their own problems in addition to making timely informed decisions. Krell, Giroux, Guido et al. (2020) asserted that the use of mobile phone applications enables smallholder farmers to achieve higher incomes, with lower transaction and distribution costs from output sales as well as input supplies. 
Creative Commons User License: CC BY-NC-ND

Abstracted by: EBSCOhost, Electronic Journals Service (EJS), Google Scholar, Journal Seek, Scientific Commons,

Food and Agricultural Organization (FAO), CABI and Scopus

http://eoi.citefactor.org/10.11226/v25i1
Journal of Agricultural Extension

Vol. 25 (1) January, 2021

ISSN(e): 24086851; ISSN(Print); 1119944X

http://journal.aesonnigeria.org

http://www.ajol.info/index.php/jae

Email: editorinchief@aesonnigeria.org

In Nigeria, the mobile phone industry has played an important role in the socio-economic development of the country by creating a platform for innovation, digital inclusion and access to information exchange, finance, markets and governance to millions of citizens who have been excluded from these services (Group Special Mobile Association (GSMA), 2016; Ogunniyi and Ojebuyi, 2016). The level of internet penetration in Nigeria has been on the increase. According to Pew Research Centre (2016), 38 percent of Nigerians were reported to have access to internet in 2014, which rose to 58 percent in 2015. More so, Sennuga and Fadiji (2020) reported that the number of smartphone users in Nigeria has reached 23.3 million in 2019 from 11 million in 2014. Despite this significant increase in smartphone use and internet penetration, there is still a prevalence of digital divide in Nigeria where social and economic inequalities still hinder access, use and impact of mobile phone technologies (Worse still, many extension organisations are yet to fully exploit the benefits because of lack of uptake in the use of mobile application technologies (Chhachhar, Chen and Jin, 2016).

Literature on the use of mobile phone applications for agricultural extension service suggests it has not received much attention. Notwithstanding the growing use of smartphones and internet penetration in Nigeria, it is still unclear whether mobile phone apps are being use for agricultural extension services in Ebonyi State. Available studies tend to dwell on the use/or adoption of mobile phone in agriculture (Kaskekacharo, 2016; Ogbeide and Ele, 2017; Jaji, Abanigbe and Abass, 2017) without considering the difference between the use of mobile phone and the use of mobile phone applications for agricultural extension service delivery. It is against this backdrop that this study assessed extension agents' use of mobile phone applications for agricultural extension service delivery in Ebonyi State Agricultural Development Programme (EBADP). The findings of this study will stimulate discourse for policy development for application of mobile apps in extension organisations in Nigeria. This study is specifically set out to achieve the following objectives: (i) identify mobile phone apps used for agricultural extension service delivery in EBADP; (ii) ascertain the extent of utilization of mobile apps for agricultural extension service delivery in EBADP; (iii) examine the content of extension services delivered on mobile phone apps; and (iv) identify constraints to the use of mobile phone apps for extension service delivery in EBADP.

\section{Methodology}

This study was carried out in Ebonyi State Agricultural Development Programme (EBADP), Ebonyi State, Nigeria. The area lies on latitude $6^{0} 31^{\prime} \mathrm{N}$ and longitude $8^{0} 15^{\prime} \mathrm{E}$ (EBADEP, 2019). EBADP is saddled with the responsibility of increasing farmers' awareness on the use of innovations and improve farm practices for increasing farmers' productivity. EBADP has three zonal offices located in the three (3) senatorial zones of the State. The Zones are made up of Ebonyi North, Ebonyi Central, and Ebonyi South. According to 
Creative Commons User License: CC BY-NC-ND

Abstracted by: EBSCOhost, Electronic Journals Service (EJS), Google Scholar, Journal Seek, Scientific Commons,

Food and Agricultural Organization (FAO), CABI and Scopus

http://eoi.citefactor.org/10.11226/v25i1
Journal of Agricultural Extension

Vol. 25 (1) January, 2021

ISSN(e): 24086851; ISSN(Print); 1119944X

http://journal.aesonnigeria.org

http://www.ajol.info/index.php/jae

Email: editorinchief@aesonnigeria.org

EBADP (2019) record, the population 'of extension agents in the respective zonal offices are: Ebonyi North 37, Ebonyi Central 31, and Ebonyi South 32, totalling one hundred (100) EAs.

All the 100 EAs in the three zones of the State were used for the study. Data were sourced with the aid of structured questionnaire. The data were analysed using percentage and mean score derived from 4-point Likert-type scale with cut-off point of 2.5 .

\section{Results and Discussion}

\section{Mobile Phone Apps Used for Agricultural Extension Service Delivery in EBADP}

Table 1 shows that the predominant mobile apps that have been used for extension service delivery in EBADP were: WhatsApp (76.0\%), and Facebook (53.0\%). However, Instagram (11.0\%), and telegram (11.0\%) are applied by few for agricultural extension service delivery in EBADP. Unfortunately, the finding shows that besides social media mobile apps, the government and management of EBADP have not been able to develop any specific mobile apps for agricultural extension service delivery in EBADP.

This situation is worrisome considering that other African countries like Kenya, Botswana, Uganda, Tanzania and the Ivory Coast are already harnessing the gains of mobile apps in agricultural sector (Costopoulou et al., 2016; Kumar and Karthikeyan, 2019), Nigeria appears to be lagging behind. This is apparently due to the absence of clear-cut government policy on the use of mobile apps for public agricultural extension service delivery in EBADP. Trendov, Varas and Zeng (2019) concurred to the above assertion by stating that the lack of clear cut regulatory and policy framework for e-agriculture is the major impediment to the actualization of the global digitalisation process.

Table 1: Mobile apps use for extension service delivery in EBADP

\begin{tabular}{ll}
\hline Mobile apps & Percentage $^{*}$ \\
\hline WhatsApp & 76.0 \\
Instagram & 25.0 \\
Facebook & 53.0 \\
Telegram & 11.0 \\
\hline
\end{tabular}

${ }^{*}$ Multiple responses recorded

\section{Extent of Utilization of Mobile Apps for Agricultural Extension Service Delivery in EBADP}

Furthermore, the result in Table 2 shows that the extent of use of the mobile apps for agricultural extension service delivery were WhatsApp $(M=3.2)$ and Facebook $(M=2.8)$. Apparently, the finding indicates that the extent of utilisation of mobile apps for extension services in EBADP is very low. This finding indicates the lack of interest from the public extension organisation in 
Creative Commons User License: CC BY-NC-ND

Abstracted by: EBSCOhost, Electronic Journals Service (EJS), Google Scholar, Journal Seek, Scientific Commons,

Food and Agricultural Organization (FAO), CABI and Scopus

http://eoi.citefactor.org/10.11226/v25i1
Journal of Agricultural Extension

Vol. 25 (1) January, 2021

ISSN(e): 24086851; ISSN(Print); 1119944X

http://journal.aesonnigeria.org

http://www.ajol.info/index.php/jae

Email: editorinchief@aesonnigeria.org

deploying mobile phone apps for agricultural extension service delivery and highlights the need for attention from the government to speed-up its application in agricultural extension. This is in line with the finding of Kumar and Karthikeyan (2019) who reported that despite the widespread penetration of mobile apps world over in all sectors, it application to agriculture is to lesser extent. This calls for urgent action to improve condition that favours the use of mobile apps for extension service delivery in EBADP.

Table 2: Extent of use of mobile apps for extension service delivery

\begin{tabular}{ll}
\hline Mobile apps & Mean score \\
\hline WhatsApp & $3.2^{\star}$ \\
Instagram & 2.3 \\
Facebook & $2.8^{\star}$ \\
Telegram & 1.5 \\
\hline
\end{tabular}

${ }^{*}$ Above 2.5 cut-off point

\section{Components of Extension Services Delivered on Mobile Phone Apps}

The components of EBADP extension services that have been successful extended using mobile apps were assessed (Table 3). The four components of EBADP services used for the rating were: crop, livestock, fishery and agroforestry. The result shows that most of the crop component of EBADP extension services extended via mobile apps were: lowland rice production $(65 \%)$, cassava/maize/vegetable production (58\%), upland rice production $(47 \%)$, and yam minisett (36\%). However, the livestock component was lowly extended using mobile apps as indicated as the result. The recommended packages extended under this component were sheep/goat rearing (23\%) and improved housing for birds (27\%). Similarly, the fish component exhibited low level of extension as only $12 \%$ of the homestead fish pond production package was extended using mobile apps. The recommended packages extended under agro-forestry component were: plantain/banana/cocoa yam $(10 \%)$, Bee keeping $(8 \%)$, and homestead snail farming (3\%), suggesting that this component has not received much mobile apps extension service delivery in EBADP. Overall, the result shows that of all these components, only the crop component somewhat has been extensively extended using mobile apps. Thus, mobile apps have been highly underutilized for extension of livestock, fishery, and agro-forestry components of EBADP extension services, resulting in low utilization of mobile apps for extension service delivery in EBADP. This finding is not surprising considering the fact that phone calls and short message service (SMS) are the most use features of mobile phones for agricultural extension services in Nigeria (Alakpa, Afolabi and Ighalo, 2019). 
Creative Commons User License: CC BY-NC-ND

Abstracted by: EBSCOhost, Electronic Journals Service (EJS),

Google Scholar, Journal Seek, Scientific Commons,

Food and Agricultural Organization (FAO), CABI and Scopus

http://eoi.citefactor.org/10.11226/v25i1
Journal of Agricultural Extension

Vol. 25 (1) January, 2021

ISSN(e): 24086851; ISSN(Print); 1119944X

http://journal.aesonnigeria.org

http://www.ajol.info/index.php/jae

Email: editorinchief@aesonnigeria.org

Table 3: Components of EBADP extension services delivered using mobile apps

\begin{tabular}{lll}
\hline Component & Recommended Packages & Percentage \\
\hline Crop & Yam minisett technique & 36.0 \\
& Cassava/maize/vegetable & 58.0 \\
& production & \\
& Cassava//maize/cowpea & 24.0 \\
& Upland rice production & 47.0 \\
& Lowland rice production & 65.0 \\
Livestock & Sheep/goat rearing & 23.0 \\
& Artificial brooding of local chicks & - \\
& Rabbitary & - \\
\multirow{5}{*}{ Fishery } & Improved housing for birds & 27.0 \\
Agro-forestry & Homestead fish pond production & 12.0 \\
& Plantain/banana/cocoa yam & 10.0 \\
& Homestead snail farming & 3.0 \\
& Bee keeping & 8.0 \\
\hline
\end{tabular}

Constraints to Use of Mobile apps for extension service delivery in EBADP

$C$ The results indicate that the low utilization of mobile apps for extension service delivery in EBADP was due to: unavailability of network coverage in rural areas (84\%), lack of institutional policy for application of mobile apps in extension service delivery (75\%), low ownership of smart phones among farmers due to high cost $(73 \%)$, poor farmers' knowledge on the use of mobile apps $(67 \%)$, poor internet connectivity $(66 \%)$, unstable electricity $(64 \%)$, and lack/inadequate training programmes on mobile apps use for extension service delivery (48\%) (Table 4). This finding conforms to that of Shanthya and Elakkiya (2017) who reported that lack/inadequate training programmes for extension agents has contributed to their inability to use mobile apps for extension service delivery. Cost has been identified as a major hindrance to smartphone ownership in developing countries (International Telecommunication Union (ITU), 2018). Jayanthi and Asokhan (2016) observed that the absence of public sector infrastructure such as power supply, and internet facilities impede access to ICTs such mobile apps.

The absence of clear-cut institutional policy for the use of mobile apps for extension service delivery is a hindrance to digitalization of extension service delivery in EBADP. According to Trendov et al. (2019), the failure of government in most developing countries to fashion out clear cut regulatory and policy framework for e-agriculture undermines the actualization of the global digitalisation process. Government policy should focus on providing the basic conditions that are necessary for the use of mobile phone apps in agricultural extension. These include: infrastructure and connectivity (mobile subscriptions, network coverage, internet access, and electricity supply), affordability, and improving ICT education. 
Creative Commons User License: CC BY-NC-ND

Abstracted by: EBSCOhost, Electronic Journals Service (EJS), Google Scholar, Journal Seek, Scientific Commons,

Food and Agricultural Organization (FAO), CABI and Scopus

http://eoi.citefactor.org/10.11226/v25i1
Journal of Agricultural Extension

Vol. 25 (1) January, 2021

ISSN(e): 24086851; ISSN(Print); 1119944X

http://journal.aesonnigeria.org

http://www.ajol.info/index.php/jae

Email: editorinchief@aesonnigeria.org

The inability of rural farmers to access internet network that will enable their access to content of mobile apps has continued to constrain the use of mobile apps for extension service delivery. In most rural settings, internet network coverage remains limited despite effort by government and telecommunication service providers to upgrade broadband to higher quality network like 5G, 4G, and 3G. According to GSMA (2019), only a third of rural people in developing countries like Nigeria have network coverage in their areas. GSMA (2018) contended that despite recent increase in mobile phones ownership in Africa and Asia countries, there are still about 3.8 billion people who have remained offline and many of them are located in rural and remote areas.

Low ownership of smartphones among farmers was identified as another constraint to the use of mobile apps for extension service delivery in EBADP. Smartphone has become a major device that enables owners to access internet. It is important to point out that despite the falling prices of mobile phones, rural farmers still consider it very expensive because of high incidence of poverty in the rural areas. Consequently, many of them settle for non-internet enabled mobile phones for call and text messaging services. ITU (2018) corroborated this assertion by stating that 7 out of every 10 poorest households in the world have mobile phone, which is not internet-enabled smartphones. The situation where smartphone owners are unable to access internet owing to poor connectivity also present serious challenge to the use of mobile apps for extension service delivery in EBADP. According to GSMA (2018), the introduction of mobile phone technologies in rural areas can be very challenging because of the limited network coverage and high illiteracy rate. The absent of basic ICT infrastructure, particularly in very remote rural communities coupled with the costs associated with procuring smartphones present a major challenge in rural areas where poverty rates are already high, particularly in developing countries.

Table 4: Constraints to the use of mobile apps for extension service delivery

\begin{tabular}{ll}
\hline Constraints & Percentage \\
\hline High cost of smartphones & 62.0 \\
Poor internet connectivity & 66.0 \\
Poor farmers' knowledge on the use of mobile apps & 67.0 \\
High cost of data subscription & 66.0 \\
Low ownership of smart phones among farmers due to high cost & 73.0 \\
Lack of institutional policy for mobile apps extension service & 75.0 \\
Unstable electricity & 64.0 \\
Unavailability of network coverage in rural area & 86.0 \\
Lack/inadequate training programmes on mobile apps use & 48.0 \\
\hline
\end{tabular}

${ }^{*}$ Multiple responses recorded 
Creative Commons User License: CC BY-NC-ND

Abstracted by: EBSCOhost, Electronic Journals Service (EJS), Google Scholar, Journal Seek, Scientific Commons,

Food and Agricultural Organization (FAO), CABI and Scopus

http://eoi.citefactor.org/10.11226/v25i1
Journal of Agricultural Extension

Vol. 25 (1) January, 2021

ISSN(e): 24086851; ISSN(Print); 1119944X

http://journal.aesonnigeria.org

http://www.ajol.info/index.php/jae

Email: editorinchief@aesonnigeria.org

\section{Conclusion and Recommendations}

WhatsApp and Facebook were the predominant mobile apps used for extension service delivery in EBADP. Meanwhile, Instagram, and telegram were not applied by many for agricultural extension service delivery in EBADP. Thus, WhatsApp and Facebook mobile apps have been extensively used for agricultural extension service delivery. The study established that crop production remains the most successfully extended EBADP's extension programme using mobile apps. The most recommended packages in the crop component extended via mobile apps were: lowland rice production, cassava/maize/vegetable production, upland rice production, and yam minisett. The study further established that the low utilization of mobile apps for extension service delivery in EBADP was due to unavailability of network coverage in rural area and lack of institutional policy for application of mobile apps in extension service delivery, and low ownership of smartphones among farmers. Considering the advantages of mobile phone apps in reaching vast clients with timely farming information, it becomes pertinent that these constraints are addressed headlong to fast-track effective application of mobile apps in extension organization for extension service delivery.

Government should initiate e-extension policy that will make it mandatory for public extension organisations to incorporate mobile apps extension services into their programmes to complement the ineffective and inefficient traditional extension system. The policy should focus on providing basic infrastructure such as stable electricity, network coverage, access to internet, and smartphones to support effective use of mobile apps for extension service delivery. The management should develop specific mobile apps to complement the already existing apps, which will aid effective extension service delivery in EBADP. The government and management of extension organisations should organize training programmes for extension agents on the use of mobile apps for extension service delivery. This undoubtedly will improve efficiency and effective extension service delivery.

\section{References}

Alakpa, S.O.E., Afolabi, S.O. and Ighalo, I.J. (2019). Assessment of extension agents' perception of mobile phone usage for communication with farmers in Edo South of Edo State, Nigeria. Universal Journal of Agricultural Research, 7(3): 131-135.

Asa, U.A. and Uwem, C.A. (2017). Utilization of mobile phones for agricultural purposes by farmers in Itu Area, Nigeria. European Scientific Journal, 13(9): 395-402.

Chhachhar, A. R., Chen, C. and Jin, J. (2016). Mobile phone impact on agriculture and price information among farmers. Indian Journal of Science and Technology, 9(39): 1-11.

Costopoulou, C., Ntaliani, M. and Karetsos, S. (2016). Studying mobile apps for agriculture. IOSR Journal of Mobile Computing \& Application (IOSR-JMCA), 3(6): 44-99. 
Creative Commons User License: CC BY-NC-ND

Abstracted by: EBSCOhost, Electronic Journals Service (EJS), Google Scholar, Journal Seek, Scientific Commons,

Food and Agricultural Organization (FAO), CABI and Scopus

http://eoi.citefactor.org/10.11226/v25i1
Journal of Agricultural Extension

Vol. 25 (1) January, 2021

ISSN(e): 24086851; ISSN(Print); 1119944X

http://journal.aesonnigeria.org

http://www.ajol.info/index.php/jae

Email: editorinchief@aesonnigeria.org

Danso-Abbeam, G., Ehiakpor, D.S. and Aidoo, R. (2018). Agricultural extension and its effects on farm productivity and income: Insight from Northern Ghana.

Agriculture \& Food Security, 7(74): 1-10.

Ebonyi State Agricultural Development Programme (EBADP) (2019). Official report of staff strength in EBADP. Abakaliki: EBADP

Group Special Mobile Association (GSMA) (2016). The mobile economy Africa 2016. Retrieved from

https://www.gsmaintelligence.com/research/?file=3bc21ea879a5b217b64d62f a24c55bdf\&download

Group Special Mobile Association (GSMA) (2018). Enabling rural coverage: Regulatory and policy recommendations to foster mobile broadband coverage in developing countries. London: GSMA Report.

Group Special Mobile Association (GSMA) (2019). The mobile economy. London: GSMA Intelligence.

International Telecommunication Union (ITU) (2018). Measuring the Information Society Report: Volume 1. Geneva: ITU.

Jaji, M.F.O., Abanigbe, S.A. and Abass, B.O. (2017). Mobile phone as an extension tool among female agricultural practitioners in Lagos State Nigeria. Journal of Agricultural Extension, 21(3): 66-79.

Jayanthi, M. and Asokhan, M. (2016). Constraints faced by m-Kisan users. Journal of Extension Education, 28(1): 134-142.

Kaskekacharo, D. (2016). The use of mobile phones in agricultural extension in Southern Ethiopia. PhD Thesis Submitted to Sokoine University of Agriculture, Morogoro, Tanzania.

Krell, N.T., Giroux, S.A., Guido, Z., Hannah, C., Lopus, S.E., Caylor, K.K. and Evans, T.P. (2020). Smallholder farmers' use of mobile phone services in central Kenya. Climate and Development, DOI: 10.1080/17565529.2020.1748847

Kumar, S.A. and Karthikeyan, C. (2019). Status of mobile agricultural apps in the global mobile ecosystem. International Journal of Education and Development using Information and Communication Technology (IJEDICT), 15(3), 63-74.

National Bureau of Statistics (NBS) (2019). Nigerian gross domestic product (GDP) report 2019. nigerianstat.gov.ng

Ogbeide, O.A. and Ele, I. (2017). An analysis of mobile phone use in Nigerian agricultural development. International Journal of ICT Research in Africa and the Middle East, 6(2): 29-46.

Ogunniyi, M.D. and Ojebuyi, B.R. (2016). Mobile phone use for agribusiness by farmers in Southwest Nigeria. Journal of Agricultural Extension, 20(2): 172187.

Oladele, O.I. (2015). Features of agricultural extension models and policy in selected sub - Saharan Africa countries. Journal of Agriculture and Environment for International Development, 105(1): 35-44.

Pew Research Centre (2016). Smartphone ownership and internet usage continues to climb in emerging economies. Retrieved from https://www.pewresearch.org/global/2016/02/22/internet-access-growingworldwide-but-remains-higher-in-advanced-economies/

Sennuga, S.O. (2019). Use of Information and Communication Technologies (ICTs) among Smallholder Farmers and Extension Workers and its Relevance to Sustainable Agricultural Practices. A PhD Thesis, Coventry University, United Kingdom. 
Creative Commons User License: CC BY-NC-ND

Abstracted by: EBSCOhost, Electronic Journals Service (EJS), Google Scholar, Journal Seek, Scientific Commons,

Food and Agricultural Organization (FAO), CABI and Scopus

http://eoi.citefactor.org/10.11226/v25i1
Journal of Agricultural Extension

Vol. 25 (1) January, 2021

ISSN(e): 24086851; ISSN(Print); 1119944X

http://journal.aesonnigeria.org

http://www.ajol.info/index.php/jae

Email: editorinchief@aesonnigeria.org

Sennuga, S.O. and Fadiji, T.O. (2020). Effectiveness of traditional extension models among rural dwellers in Subsaharan African communities. International Journal of Advanced Research, 8(04): 401-415.

Shanthya, M.S. and Elakkiya, S. (2017). Constraints encountered by famers in ICT utilization - An analysis. International Journal of Agriculture Innovations and Research, 6(2): 346-347.

Trendov, N.M., Varas, S. and Zeng, M. (2019). Digital technologies in agriculture and rural areas. Briefing Paper. Food and Agriculture Organization of the United Nations, Rome.

Urama, N.E. and Nfor, Y.D. (2018). Evaluating food crop sector performance in Nigeria (1999-2016). AfriHeritage Working Paper 2018-002, African Heritage Institution, Enugu, pp. 1-20. 